\title{
Low Chemically Cross-linked PAM/C-dot Hydrogel with Robust and Super Stretchability in both as-Prepared and Swelling Equilibrium States
}

Meng Hu, ${ }^{a}$ Xiaoyu Gu, ${ }^{a}$ Yang Hu, ${ }^{* a, b}$ Tao Wang, ${ }^{a}$ Jian Huang, ${ }^{a}$ Chaoyang Wang ${ }^{*, a}$

\author{
${ }^{a}$ Research Institute of Materials Science, South China University of Technology, \\ Guangzhou 510640, China \\ ${ }^{b}$ Institute of Biomaterials, College of Materials and Energy, South China Agricultural \\ University, Guangzhou 510642, China
}

Table S1. Compositions of reactants for the synthesis of the $\mathrm{ABC}_{\mathrm{n}}$ hydrogels

\begin{tabular}{|c|c|c|c|c|c|c|}
\hline \multirow[b]{2}{*}{$\begin{array}{l}\text { Sample } \\
\left(A B C_{n}\right)\end{array}$} & \multicolumn{6}{|c|}{ Composition } \\
\hline & $\begin{array}{l}\mathrm{H}_{2} \mathrm{O} \\
(\mathrm{mL})\end{array}$ & $\begin{array}{l}\text { Am } \\
(\mathrm{g})\end{array}$ & $\begin{array}{c}\text { C-dots } \\
\text { (g) }\end{array}$ & $\begin{array}{l}\text { APS } \\
(\mathrm{mg})\end{array}$ & $\begin{array}{c}\text { BIS } \\
(\mathrm{mg})\end{array}$ & $\begin{array}{c}\text { TEMED } \\
(\mu \mathrm{L})\end{array}$ \\
\hline $\mathrm{ABC}_{0}$ & 5 & 1.35 & 0 & 5 & 0.385 & 24 \\
\hline $\mathrm{ABC}_{1}$ & 5 & 1.35 & 0.05 & 5 & 0.385 & 24 \\
\hline $\mathrm{ABC}_{1.5}$ & 5 & 1.35 & 0.075 & 5 & 0.385 & 24 \\
\hline $\mathrm{ABC}_{2}$ & 5 & 1.35 & 0.1 & 5 & 0.385 & 24 \\
\hline $\mathrm{ABC}_{2.5}$ & 5 & 1.35 & 0.125 & 5 & 0.385 & 24 \\
\hline $\mathrm{ABC}_{3}$ & 5 & 1.35 & 0.15 & 5 & 0.385 & 24 \\
\hline $\mathrm{ABC}_{3.5}$ & 5 & 1.35 & 0.175 & 5 & 0.385 & 24 \\
\hline $\mathrm{ABC}_{4}$ & 5 & 1.35 & 0.2 & 5 & 0.385 & 24 \\
\hline
\end{tabular}


Table S2. Compositions of reactants for the synthesis of the $\mathrm{AB}_{\mathrm{m}} \mathrm{C}$ hydrogels

\begin{tabular}{lcccccc}
\hline \multirow{6}{*}{$\begin{array}{c}\text { Sample } \\
\left(\mathbf{A B} \mathbf{m}_{\mathbf{m}} \mathbf{C}\right)\end{array}$} & $\begin{array}{c}\mathbf{H}_{\mathbf{2}} \mathbf{O} \\
(\mathbf{m L})\end{array}$ & $\begin{array}{c}\mathbf{A m} \\
(\mathbf{g})\end{array}$ & $\begin{array}{c}\text { C-dots } \\
(\mathbf{g})\end{array}$ & $\begin{array}{c}\text { APS } \\
(\mathbf{m g})\end{array}$ & $\begin{array}{c}\text { MBA } \\
(\mathbf{m g})\end{array}$ & $\begin{array}{c}\text { TEMED } \\
(\mu \mathrm{L})\end{array}$ \\
\hline $\mathrm{AB}_{0.011} \mathrm{C}$ & 5 & 1.35 & 0.125 & 5 & 0.154 & 24 \\
$\mathrm{AB}_{0.017} \mathrm{C}$ & 5 & 1.35 & 0.125 & 5 & 0.231 & 24 \\
$\mathrm{AB}_{0.029} \mathrm{C}$ & 5 & 1.35 & 0.125 & 5 & 0.385 & 24 \\
$\mathrm{AB}_{0.040} \mathrm{C}$ & 5 & 1.35 & 0.125 & 5 & 0.539 & 24 \\
$\mathrm{AB}_{0.051} \mathrm{C}$ & 5 & 1.35 & 0.125 & 5 & 0.693 & 24 \\
$\mathrm{AB}_{0.063} \mathrm{C}$ & 5 & 1.35 & 0.125 & 5 & 0.847 & 24
\end{tabular}

Table S3. Mechanical properties of the as-prepared $\mathrm{ABC}_{\mathrm{n}}$ hydrogels

\begin{tabular}{|c|c|c|c|c|c|}
\hline $\begin{array}{l}\text { Sample } \\
\left(A B C_{n}\right)\end{array}$ & $\begin{array}{l}\text { Tensile } \\
\text { strength } \\
\text { (KPa) } \\
\end{array}$ & $\begin{array}{l}\text { Elongation } \\
\text { at break } \\
(\%)\end{array}$ & $\begin{array}{l}\text { Young's } \\
\text { modulus } \\
(\mathrm{KPa}) \\
\end{array}$ & $\begin{array}{l}\text { Compressive } \\
\text { strength } \\
(\mathrm{MPa}) \text { at } 85 \%\end{array}$ & $\begin{array}{l}\text { Fracture } \\
\text { energy } \\
\left(\mathrm{J} / \mathrm{m}^{-2}\right) \\
\end{array}$ \\
\hline $\mathrm{ABC}_{0}$ & $52 \pm 12$ & $705 \pm 138$ & $14.6 \pm 1.6$ & $211 \pm 44$ & $173 \pm 13$ \\
\hline $\mathrm{ABC}_{1}$ & $94 \pm 3$ & $1626 \pm 87$ & $12.4 \pm 1.3$ & $172 \pm 11$ & $595 \pm 35$ \\
\hline $\mathrm{ABC}_{1.5}$ & $121 \pm 5$ & $2406 \pm 178$ & $15 \pm 0.5$ & $160 \pm 16$ & $1085 \pm 92$ \\
\hline $\mathrm{ABC}_{2}$ & $163 \pm 15$ & $3529 \pm 108$ & $17.6 \pm 1.4$ & $114 \pm 10$ & $2185 \pm 177$ \\
\hline $\mathrm{ABC}_{2.5}$ & $156 \pm 18$ & $3896 \pm 239$ & $14.8 \pm 1.4$ & $90 \pm 4$ & $2310 \pm 141$ \\
\hline $\mathrm{ABC}_{3}$ & $118 \pm 9$ & $4266 \pm 66$ & $14.2 \pm 1.2$ & $79 \pm 8$ & $2357 \pm 109$ \\
\hline $\mathrm{ABC}_{3.5}$ & $87 \pm 8$ & $3668 \pm 143$ & $7 \pm 0.8$ & $74 \pm 15$ & $1517 \pm 209$ \\
\hline $\mathrm{ABC}_{4}$ & $68 \pm 5$ & $3096 \pm 119$ & $4.6 \pm 0.6$ & $68 \pm 10$ & $1046 \pm 88$ \\
\hline
\end{tabular}

Table S4. Mechanical properties of the as-prepared $\mathrm{AB}_{\mathrm{m}} \mathrm{C}$ hydrogels

\begin{tabular}{llllll}
\hline $\begin{array}{l}\text { Sample } \\
\left(\mathbf{A B C} \mathbf{n}_{\mathbf{n}}\right)\end{array}$ & $\begin{array}{l}\text { Tensile } \\
\text { strength } \\
(\mathrm{KPa})\end{array}$ & $\begin{array}{l}\text { Elongation } \\
\text { at break } \\
(\%)\end{array}$ & $\begin{array}{l}\text { Young's } \\
\text { modulus } \\
(\mathbf{K P a})\end{array}$ & $\begin{array}{l}\text { Compressive } \\
\text { strength } \\
(\mathbf{M P a}) \text { at } 85 \%\end{array}$ & $\begin{array}{l}\text { Fracture } \\
\text { energy } \\
\left(\mathbf{J} / \mathbf{m}^{-2}\right)\end{array}$ \\
\hline $\mathrm{AB}_{0.011} \mathrm{C}$ & $30 \pm 2$ & $5111 \pm 183$ & $6.7 \pm 0.6$ & $55 \pm 7$ & $955 \pm 53$ \\
$\mathrm{AB}_{0.017} \mathrm{C}$ & $100 \pm 13$ & $5027 \pm 272$ & $8.1 \pm 1.5$ & $75 \pm 12$ & $2171 \pm 156$ \\
$\mathrm{AB}_{0.029} \mathrm{C}$ & $156 \pm 18$ & $3896 \pm 239$ & $14.8 \pm 1.4$ & $93 \pm 8$ & $2310 \pm 141$ \\
$\mathrm{AB}_{0.040} \mathrm{C}$ & $149 \pm 7$ & $2188 \pm 36$ & $15.7 \pm 1.7$ & $162 \pm 15$ & $1283 \pm 127$ \\
$\mathrm{AB}_{0.051} \mathrm{C}$ & $131 \pm 24$ & $1625 \pm 265$ & $29.6 \pm 2.3$ & $375 \pm 23$ & $896 \pm 45$ \\
$\mathrm{AB}_{0.063} \mathrm{C}$ & $107 \pm 7$ & $1027 \pm 113$ & $34.1 \pm 1.6$ & $423 \pm 18$ & $516 \pm 38$
\end{tabular}


Table S5. The glass transition temperature $\left(T_{g}\right)$ of $\mathrm{ABC}_{n}$ hydrogels

\begin{tabular}{lccccccccc}
\hline $\begin{array}{l}\text { Samples } \\
\left(\mathbf{A B C} \mathbf{n}_{\mathbf{n}}\right)\end{array}$ & $\mathrm{PAM}$ & $\mathrm{ABC}_{0}$ & $\mathrm{ABC}_{1}$ & $\mathrm{ABC}_{1.5}$ & $\mathrm{ABC}_{2}$ & $\mathrm{ABC}_{2.5}$ & $\mathrm{ABC}_{3}$ & $\mathrm{ABC}_{3.5}$ & $\mathrm{ABC}_{4}$ \\
\hline $\mathbf{T g}\left({ }^{\circ} \mathbf{C}\right)$ & 163.2 & 185.5 & 183.7 & 182.5 & 179.5 & 177.4 & 175.8 & 174.2 & 173.1
\end{tabular}

Table S6. Properties of swollen $\mathrm{ABC}_{\mathrm{n}}$ hydrogel

\begin{tabular}{cccc}
\hline $\begin{array}{c}\text { Sample } \\
\left(\mathbf{A B C} \mathbf{n}_{\mathbf{n}}\right)\end{array}$ & $\begin{array}{c}\text { Water content in } \\
\text { Swelling equilibrium } \\
(\%)\end{array}$ & $\begin{array}{c}\text { Tensile } \\
\text { strength } \\
(\mathbf{k P a})\end{array}$ & $\begin{array}{c}\text { Elongation at } \\
\text { Break } \\
(\%)\end{array}$ \\
\hline $\mathrm{ABC}_{0}$ & 96.93 & 6.04 & 506 \\
$\mathrm{ABC}_{1}$ & 97.66 & 10.1 & 798 \\
$\mathrm{ABC}_{1.5}$ & 98.13 & 6.8 & 702 \\
$\mathrm{ABC}_{2}$ & 98.36 & 6.01 & 762 \\
$\mathrm{ABC}_{2.5}$ & 98.51 & 7.0 & 892 \\
$\mathrm{ABC}_{3}$ & 98.64 & 6.2 & 843 \\
$\mathrm{ABC}$ & & 3.4 & 678 \\
$\mathrm{ABC}_{4}$ & 98.94 & 2.0 & 645
\end{tabular}

Table S7. Properties of swollen $\mathrm{AB}_{\mathrm{m}} \mathrm{C}$ hydrogels

\begin{tabular}{cccc}
\hline $\begin{array}{c}\text { Sample } \\
\left(\mathbf{A B}_{\mathbf{m}} \mathbf{C}\right)\end{array}$ & $\begin{array}{c}\text { Water content in } \\
\text { Swelling equilibrium } \\
(\%)\end{array}$ & $\begin{array}{c}\text { Tensile } \\
\text { strength } \\
(\mathbf{k P a})\end{array}$ & $\begin{array}{c}\text { Elongation at } \\
\text { Break } \\
(\%)\end{array}$ \\
\hline $\mathrm{AB}_{0.011} \mathrm{C}$ & 99.48 & - & - \\
$\mathrm{AB}_{0.017} \mathrm{C}$ & 99.58 & - & - \\
$\mathrm{AB}_{0.029} \mathrm{C}$ & 98.51 & 7.0 & 892 \\
$\mathrm{AB}_{0.040} \mathrm{C}$ & 97.10 & 13.60 & 714 \\
$\mathrm{AB}_{0.051} \mathrm{C}$ & 96.61 & 15.26 & 731 \\
$\mathrm{AB}_{0.063} \mathrm{C}$ & 95.54 & 22.75 & 734
\end{tabular}


Table S8. The theoretical prediction and experiment data of strain of swollen $A B C_{n}$ gels

\begin{tabular}{cccc}
\hline $\begin{array}{c}\text { Sample } \\
\text { (swollen } \mathrm{ABC}_{\mathrm{n}} \text { ) }\end{array}$ & $\begin{array}{c}\text { Swelling } \\
\text { degree from } \\
\text { the initial state }\end{array}$ & $\begin{array}{c}\text { Theoretical } \\
\text { prediction strain (\%) }\end{array}$ & $\begin{array}{c}\text { Elongation } \\
\text { at Break (\%) }\end{array}$ \\
\hline $\mathrm{ABC}_{0}(\mathrm{PAM})$ & 8.8 & 342 & 506 \\
$\mathrm{ABC}_{1}$ & 11.5 & 719 & 798 \\
$\mathrm{ABC}_{1.5}$ & 14.4 & 990 & 702 \\
$\mathrm{ABC}_{2}$ & 16.6 & 1384 & 762 \\
$\mathrm{ABC}_{2.5}$ & 18.1 & 1481 & 892 \\
$\mathrm{ABC}_{3}$ & 19.8 & 1574 & 843 \\
$\mathrm{ABC}_{3.5}$ & 25.5 & 1248 & 678 \\
$\mathrm{ABC}_{4}$ & 31.5 & 980 & 645
\end{tabular}



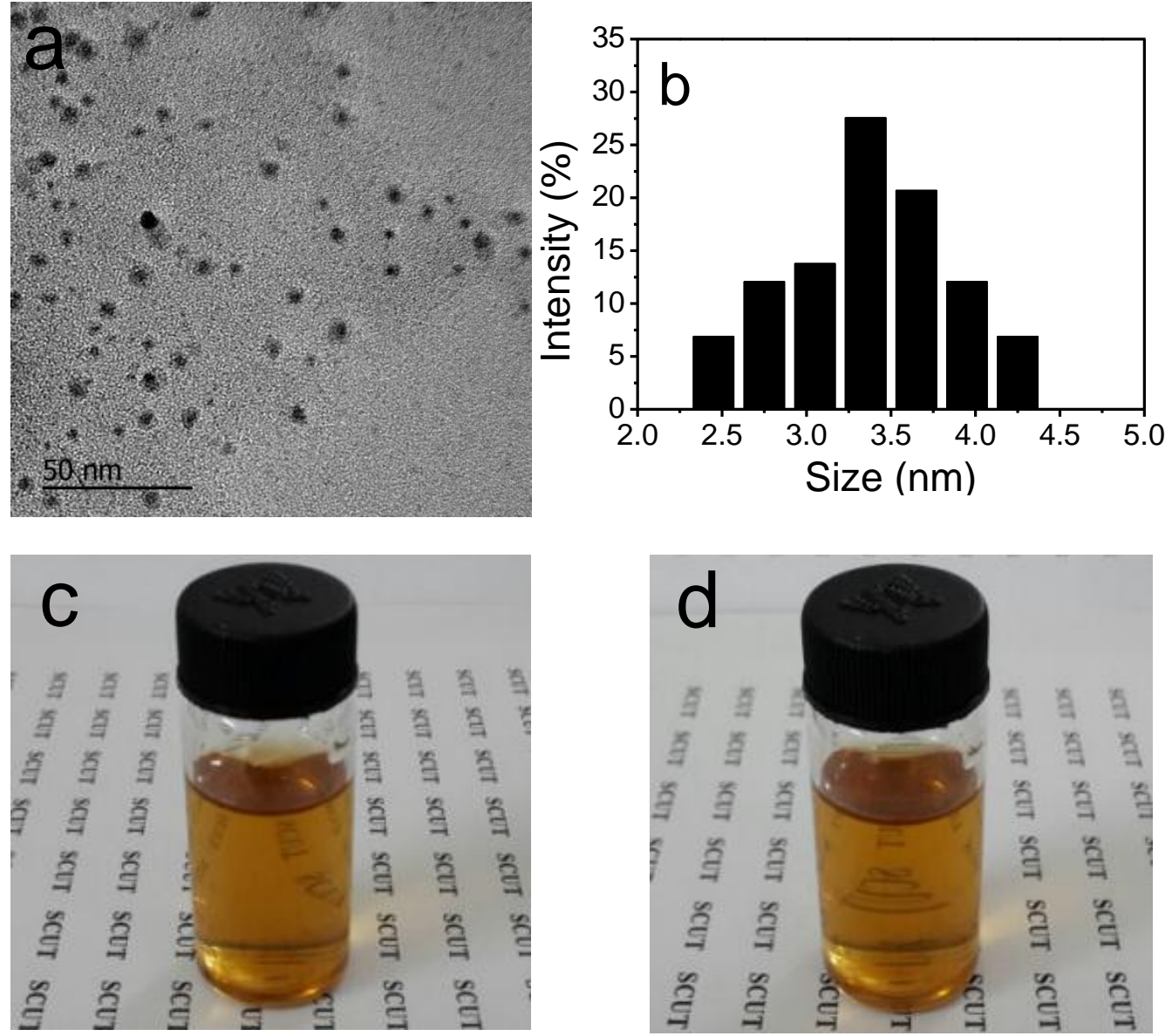

Figure S1. (a) TEM image of synthesised C-dots, scale bar: $50 \mathrm{~nm}$. (b) Size histogram of synthesised C-dots (counting 100 particles at least). (c) Photograph of fresh C-dots aqueous solution $(0.05 \mathrm{~g} / \mathrm{mL})$. (d) Photograph of C-dots aqueous solution after setting at room temperature for 60 days.
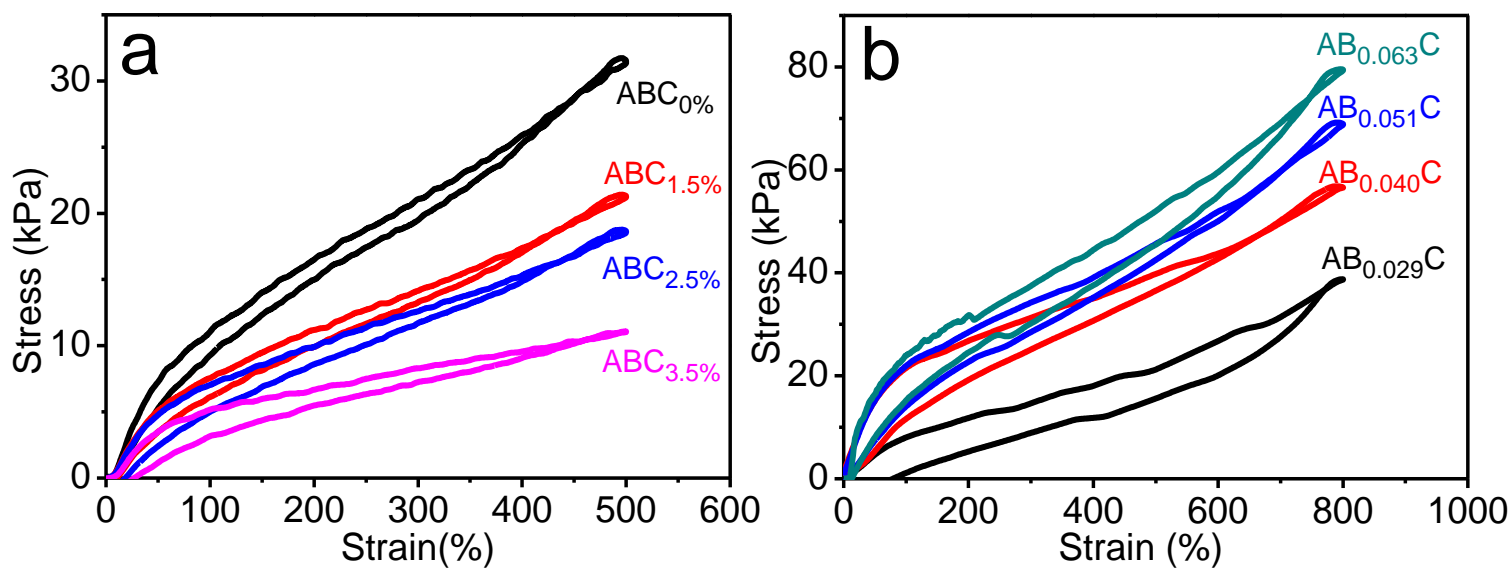

Figure S2. (a,b) Cyclic tensile tests of the as-prepared $A_{m} C_{n}$ hydrogels 

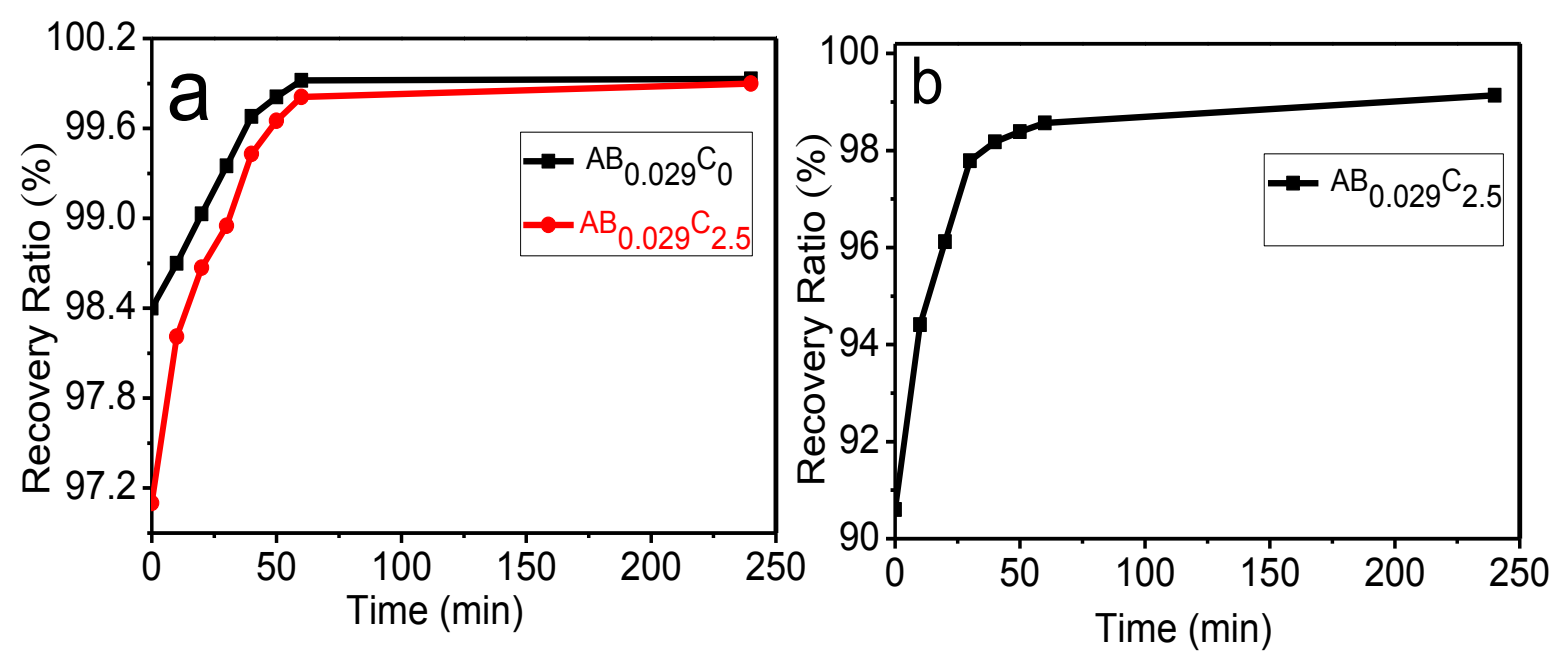

Figure S3. The recovery ratio of $\mathrm{ABC}$ hydrogel at different recovery time: (a) Elastic recovery of $\mathrm{AB}_{0.029} \mathrm{C}_{0}$ and $\mathrm{AB}_{0.029} \mathrm{C}_{2.5}$ at $500 \%$ stretching; (b) Elastic recovery of $\mathrm{AB}_{0.029} \mathrm{C}_{2.5}$ at $800 \%$ stretching.
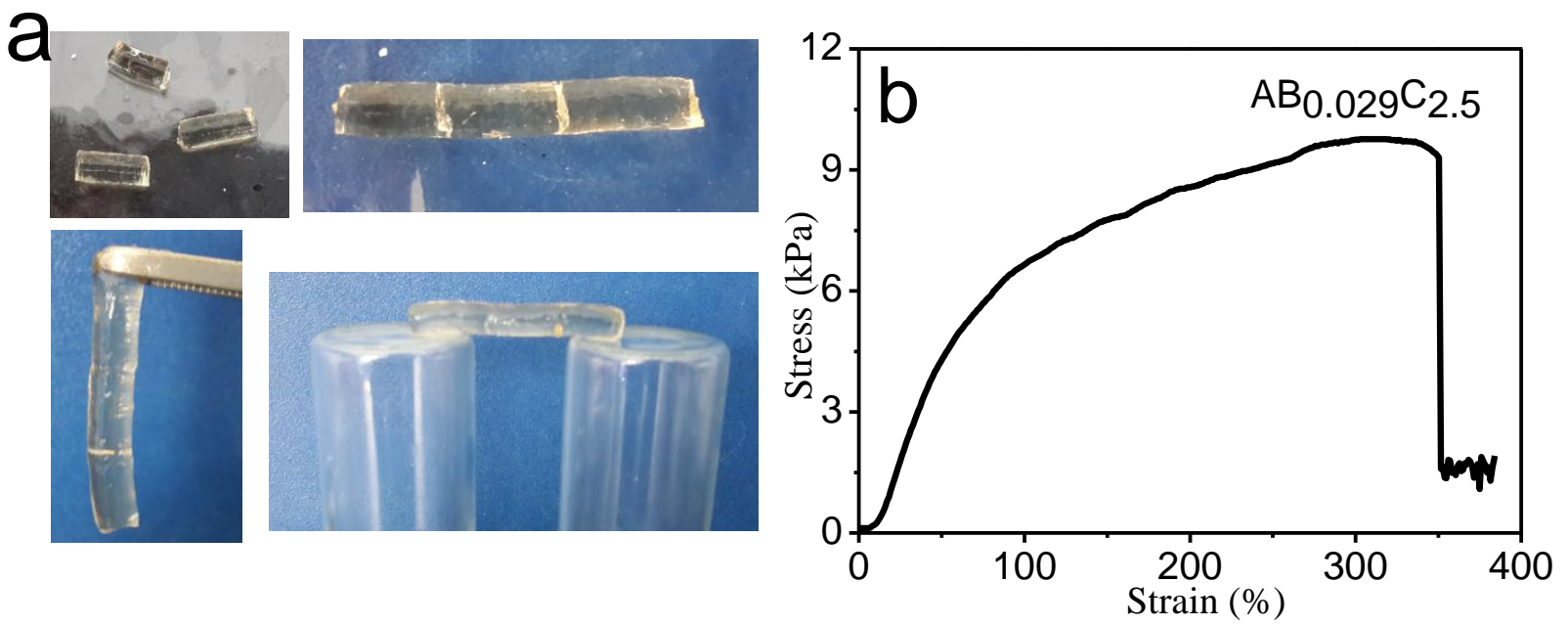

Figure S4. a) Photographs demonstrating the self-healing behavior of the $A_{m} C_{n}$ hydrogels. b) Tensile stress-strain curves of $\mathrm{AB}_{0.029} \mathrm{C}_{\mathrm{n}}$ hydrogels after self-healing for $12 \mathrm{~h}$ in room temperature. 

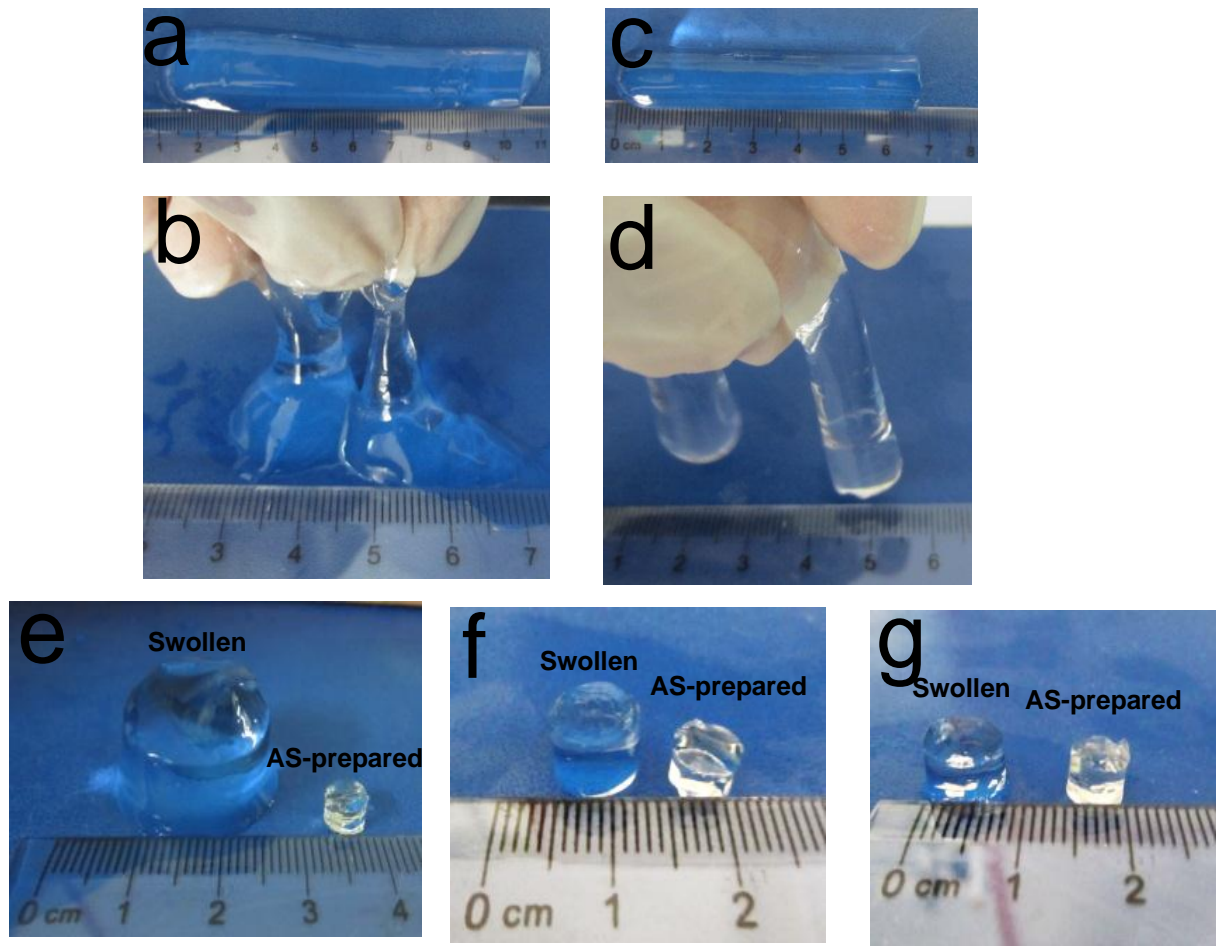

Figure S5. (a-g) Photographs of the swollen $\mathrm{AB}_{\mathrm{m}} \mathrm{C}_{\mathrm{n}}$ hydrogels: $(\mathrm{a}, \mathrm{b})$ The swollen $\mathrm{AB}_{0.011} \mathrm{C}_{2.5}$ hydrogel could not be picked up. (c,d) The swollen $\mathrm{AB}_{0.017} \mathrm{C}_{2.5}$ hydrogel could be easily picked up. (e-f) $\mathrm{AB}_{0.029} \mathrm{C}_{2.5}$ hydrogel before and after swellen in different $\mathrm{pH}$ values ( $\mathrm{pH}=11.5,6.8,1.2$, respectively).
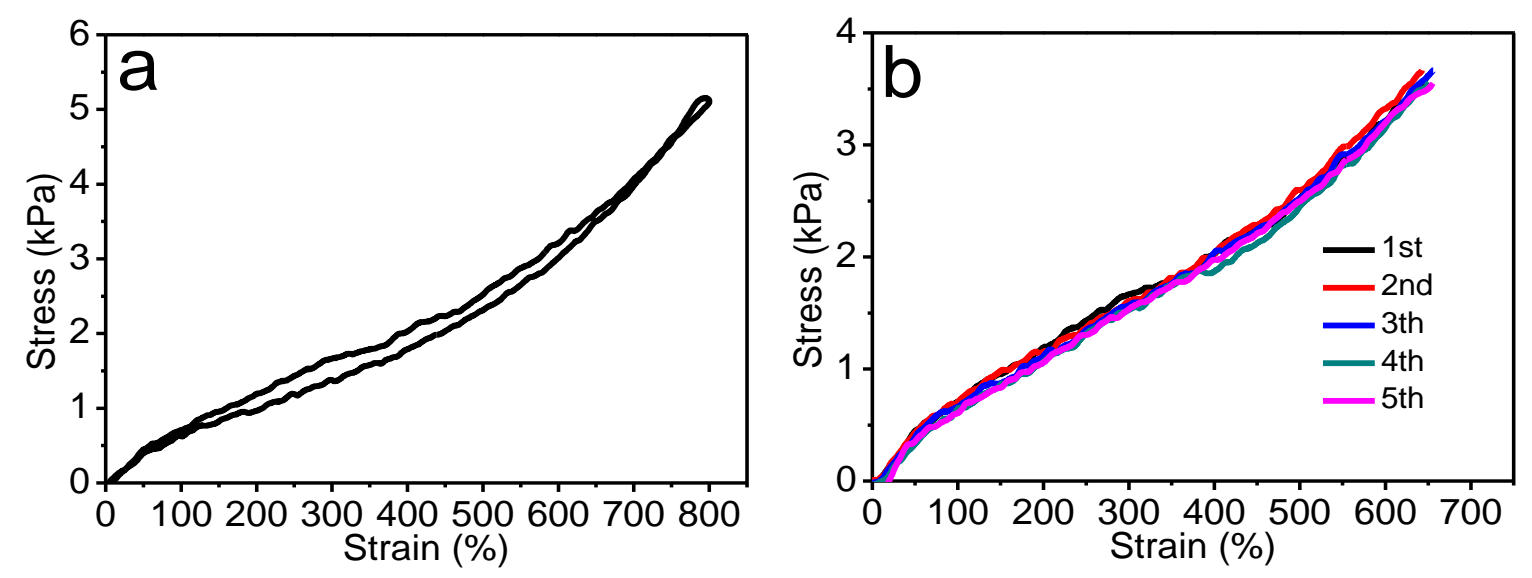

Figure S6. (a) Cyclic tensile tests of the swollen $\mathrm{AB}_{0.029} \mathrm{C}_{2.5}$ hydrogel. b) tensile tests of the swollen $\mathrm{AB}_{0.029} \mathrm{C}_{2.5}$ hydrogel with different times. 


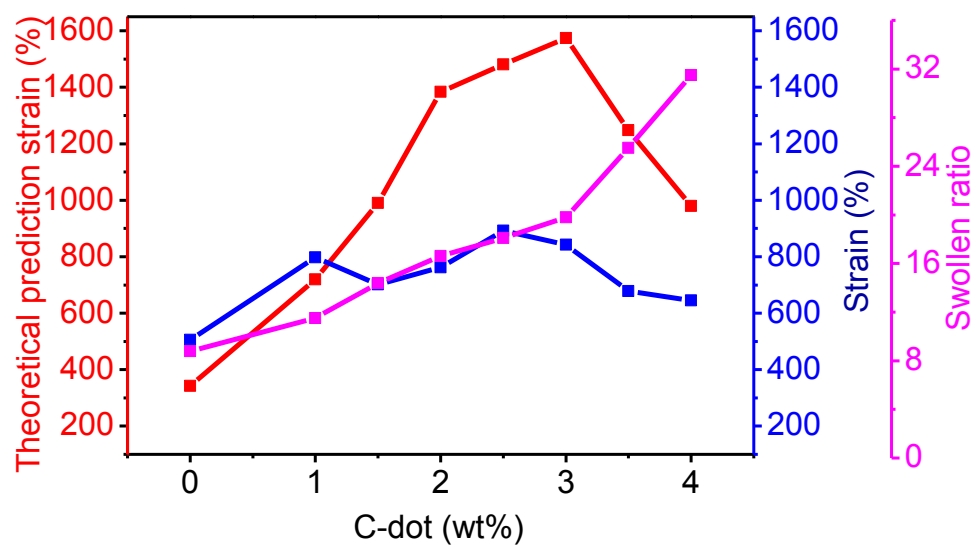

Figure S7. The theoretical prediction and experiment data of the strain of swollen $\mathrm{ABC}_{\mathrm{n}}$ gels

In this study, the theoretical prediction data of the strain for the swollen $\mathrm{ABC}_{\mathrm{n}}$ hydrogel have been calculated according to formulate:

$$
\begin{gathered}
\frac{\mathrm{a} \times \mathrm{N}}{\mathrm{Sa}_{n}}=\mathrm{La}_{n} \\
\mathrm{Ls}_{n}=\mathrm{La}_{n} \times Q r_{n}^{\frac{1}{3}} \\
\mathrm{Ss}_{n}=\frac{\mathrm{a} \times \mathrm{N}}{\mathrm{Ls}_{n}}=\mathrm{Sa}_{n} \times Q r_{n}{ }^{-\frac{1}{3}}
\end{gathered}
$$

where $\mathrm{a}$ is the monomer length, $\mathrm{N}$ is the polymerization degree of the network strand ( $\mathrm{N}$ can be estimated using the rubber elasticity theory, A. V. Tobolsky, D. W. Carlson, N. Indictor, J. Polym. Sci. 1961, 54, 175.), $\mathrm{La}_{n}$ is the end-to-end distance of crosslinked PAM chains in the as-prepared $\mathrm{ABC}_{\mathrm{n}}$ hydrogel, $\mathrm{Ls}_{n}$ is the end-to-end distance of crosslinked PAM chains in the swollen $\mathrm{ABC}_{\mathrm{n}}$ hydrogel, $Q r_{n}^{\frac{1}{3}}$ is the additional multiplicative factor because the crosslinks deform in the affine manner accompanied with the swelling (where $\mathrm{Qr}_{\mathrm{n}}$ is the swelling degree of $\mathrm{ABC}_{\mathrm{n}}$ hydrogel from the initial state), $\mathrm{Sa}_{\mathrm{n}}$ is the strain of the as-prepared $\mathrm{ABC}_{\mathrm{n}}$ hydrogel, $\mathrm{Ss}_{\mathrm{n}}$ is the theoretical prediction strain of swollen $\mathrm{ABC}_{\mathrm{n}}$ hydrogel. According to the experiment data of $\mathrm{Sa}_{\mathrm{n}}$ and $\mathrm{Qr}_{\mathrm{n}}$, the theoretical prediction data of $\mathrm{Ss}_{\mathrm{n}}$ were calculated and the results were presented in the following table and figures.

The results from the above Table S8 and Figures S7 demonstrated that the experiment data of fracture strain were approximate the theoretical prediction data at low swollen 
ratio, while became smaller than the theoretical prediction data at high swollen ratio. The experiment data of fracture strain were not always smaller than the theoretical prediction data, and decreased at a rate greater than the theoretical prediction accompanied with the increase of the swollen ratio. That might be because although the heterogeneity of the network structures became pronounced accompanied with the swelling (which led to the decrease of the fracture strain and stress at a rate greater than the theoretical prediction accompanied with the swelling), the swelling water also might act as lubrication to increase the fracture strain (Adv. Mater. 2014, 26, 5950-5956). Besides, the physical crosslinked pointes between C-dots and PAM chains maybe not be destroyed in the swollen hydrogel (The physical crosslinked points between Laponite and Poly(N-isopropylacrylamide) chains were not destroyed in the swollen hydrogel, Soft Matter 2012, 8, 774.), which could dissipate the stress (see the obviously hysteresis loop in Figure S6a) and improve the mechanical properties of the swollen $\mathrm{ABC}_{\mathrm{n}}$ hydrogel. Moreover, as mentioned in the revised manuscript, C-dots could be shifted with the PAM chains during the stretching process, which made the PAM chains more flexible, and could dissipate more stress, thus improving the mechanical properties of the swollen $\mathrm{ABC}_{\mathrm{n}}$ hydrogel. As a result, although the heterogeneity of the network structure in hydrogel became pronounced accompanied with the swelling, the swollen $\mathrm{ABC}_{\mathrm{n}}$ hydrogel still could keep excellent mechanical properties. 